\title{
Anestesi Tetes Infus Gravimetrik Ketapol sebagai Alternatif Bius Umum Secara Inhalasi Guna Menjaga Status Teranestesi pada Babi
}

\author{
(THE GRAVIMETRIC INFUSION ANAESTHESIA WITH KETAPOL \\ AS AN ALTERNATIVE GENERAL INHALATION ANESTHESIA \\ TO MAINTANACE ANESTHESIA STATUS ON PIGS)
}

\author{
I Gusti Agung Gde Putra Pemayun, I Gusti Ngurah Sudisma \\ Laboratorium Bedah dan Radiologi, Fakultas Kedokteran Hewan, \\ Universitas Udayana, Jln Sudirman, Denpasar, Bali, Indonesia \\ Tlp. (0361) 223791; Email: putrapemayun@unud.ac.id
}

\begin{abstract}
ABSTRAK
Tujuan penelitian ini adalah untuk menilai kualitas dan efektivitas penggunaaan ketapol (kombinasi ketamin-propofol) secara gravimetrik pada babi. Kualitas waktu anestesi, fungsi kardiovaskuler dan respirasi dievaluasi pada 12 ekor babi jantan berbobot sekitar $35 \pm 5 \mathrm{~kg}$. Babi dibagi dalam empat perlakuan dan masing-masing perlakuan terdiri dari tiga ekor babi sebagai ulangan. Semua hewan coba dipremedikasi dengan atropin dosis $0,03 \mathrm{mg} / \mathrm{kg}$ dicampur dengan xilazin dosis $2 \mathrm{mg} / \mathrm{kg}$ dalam satu spuit dan diinjeksikan secara intramuskuler. Babi-babi percobaan, 15 menit pascapremedikasi diinduksi dengan pemberian kombinasi ketamin $6 \mathrm{mg} / \mathrm{kg}$ dan propofol $2 \mathrm{mg} / \mathrm{kg}$ secara intravena, selanjutnya keadaan teranestesi dijaga secara gravimetrik, masing-masing melalui tetes infus intravena dengan: propofol (0,1 $\mathrm{mg} / \mathrm{kg} \mathrm{BB} / \mathrm{menit})$ (PI-P); ketamin (0,3 mg/kg BB/menit) (PI-K); kombinasi propofol-ketamin (0,1 and 0,3 $\mathrm{mg} / \mathrm{kg} \mathrm{BB} /$ menit) (PI-PK); dan inhalasi dengan isofluran 1-2\%. (PI-I). Sebelum dan selama hewan teranestesi dilakukan pemeriksaan degup jantung, capillary refilling time (CRT), frekuensi respirasi, pulsus, suhu, dan saturasi oksigen (SpO2). Kombinasi premedikasi atropin dosis 0,03 $\mathrm{mg} / \mathrm{kg}$ dicampur dengan xilazin dosis $2 \mathrm{mg} / \mathrm{kg}$ dalam satu spuit, 15 menit kemudian diinduksi dengan kombinasi ketamin $6 \mathrm{mg} / \mathrm{kg}$ dan propofol $2 \mathrm{mg} / \mathrm{kg}$ menghasilkan rataan lama kerja anestesi selama 32,33 menit, lebih lama dibandingkan dengan lima perlakuan lainnya dengan rataan waktu induksi tiga menit dan rataan waktu pemulihan 20,33 menit. Pemeliharaan anestesi dengan tetes infus intravena dengan propofol ( $0,1 \mathrm{mg} / \mathrm{kg} \mathrm{BB} / \mathrm{menit})$, atau tetes infus intravena dengan kombinasi propofol-ketamin ( 0,1 dan $0,3 \mathrm{mg} / \mathrm{kg} \mathrm{BB} / \mathrm{menit})$ menghasilkan anestesi yang aman, dan tidak menyebabkan perubahan yang ekstrim terhadap degup jantung, respirasi, suhu rektal, saturasi oksigen, pulsus, dan nilai CRT pada babi percobaan. Simpulan penelitian ini adalah metode anestesi tetes infus gravimetrik dengan kombinasi ketamin dan propofol (ketafol) dapat digunakan untuk pemeliharaan status teranestesi sebagai alternatif anestesi umum inhalasi pada babi.
\end{abstract}

Kata-kata kunci: anesthesia; gravimetric; ketamine; propofol; babi

\begin{abstract}
This study aim was to evaluate quality and effectiveness of anaesthesia by using gravimetric infusion anaesthesia with ketamine and propofol (ketafol) on pigs. The quality of anesthesia time, the cardiovascular and respiratory response of anaesthesia were evaluated in twelve male pigs with average body weight $35 \pm 5 \mathrm{~kg}$. The pigs were divided into four treatments and each treatment consisted of three pigs as repetition. All the experimental animals were premedicated with atropine $0.03 \mathrm{mg} / \mathrm{kg}$ mixed with xylazine $2 \mathrm{mg} / \mathrm{kg}$ in one syringe injected intramuscularly. Fifteen minutes after premedicated, the pigs was induced intravenously with ketamine $6 \mathrm{mg} / \mathrm{kg}$ and propofol $2 \mathrm{mg} / \mathrm{kg}$. Furthermore, the anesthetized state maintaned with gravimetric, each through infusion with propofol $(0.1 \mathrm{mg} / \mathrm{kg} / \mathrm{minute})(\mathrm{PI}-\mathrm{P})$, ketamine $(0.3 \mathrm{mg} / \mathrm{kg} /$ minute) (PIK), combination propofol-ketamin (0.1 and $0.3 \mathrm{mg} / \mathrm{kg} / \mathrm{minute}$ ) (PI-PK), and inhalation with isoflurane $1-2 \%$ (PI-I). The heart rate, pulse, respiratory rate, rectal temperature, blood oxygen saturation
\end{abstract}


(SpO2), capillary refill time (CRT) were observed before and after treatment of the anesthetic. Premedication combination of atropin $0.03 \mathrm{mg} / \mathrm{kg}$ mixed with xylazine $2 \mathrm{mg} / \mathrm{kg}$ in one syringe and then induced with ketamine $6 \mathrm{mg} / \mathrm{kg}$ and propofol $2 \mathrm{mg} / \mathrm{kg}$ showed the average length of anesthesia for 32,33 minutes, longer compared to five other treatments with average length of induction three minutes and average recovery time 20.33 minutes. Maintenance of anesthesia with propofol infusion drops $(0.1 \mathrm{mg} / \mathrm{kg} / \mathrm{minute})$, or propofolketamine infusion drops ( 0.3 and $0.1 \mathrm{mg} / \mathrm{kg} / \mathrm{minute})$ showed safer anesthesia, because they did not make drastic change of heart rate, respiratory rate, rectal temperature, oxygen saturation, pulse, and CRT value in the experimental pigs. The conclusion of this study is the methode of gravimetric intravenous infusion by using ketamine and propofol (ketafol) can be used to maintain anesthesia as an alternative general inhalation anaesthesia in pigs.

Keywords: anesthesia; gravimetric; ketamine; propofol; pig

\section{PENDAHULUAN}

Penggunaan babi sebagai hewan model pembedahan terutama untuk pembedahan laparoskopi semakin berkembang dan telah digunakan di berbagai negara. Penggunaan babi sebagai hewan model untuk berbagai metode bedah mulai giat dilaksanakan di Indonesia. Hewan babi merupakan model yang ideal untuk berbagai pelatihan teknik bedah laparoskopi. Anatomi babi secara umum memiliki kesamaan dengan anatomi manusia. Pelatihan dengan hewan babi dapat memperhalus teknik dan meningkatkan efesiensi serta keahlian (Gunanti et al., 2011).

Pembedahan tidak dapat dilakukan bila pembiusan belum dilaksanakan, maka anestesi merupakan tahapan yang sangat penting dan strategis pada tindakan pembedahan. Sejarah menunjukkan ilmu bedah mengalami revolusi yang pesat setelah eter ditemukan sebagai anestesi oleh William Thomas Green Morton pada tahun 1846 (Pretto, 2002). Anestesi mempunyai risiko yang jauh lebih besar dari prosedur pembedahan karena nyawa pasien yang dianestesi dapat terancam. Untuk itu pemilihan anestesi ideal diperlukan dalam menghasilkan analgesia, sedasi, relaksasi, ketidaksadaran (unconsciousness), keamanan dan kenyamanan untuk sistem vital, ekonomis serta mudah diaplikasikan. Sampai saat ini anestesi yang memenuhi kriteria ideal belum ada.

Anestesi umum yang sering digunakan dan dinyatakan cukup aman pada hewan adalah anestesi inhalasi. Tetapi anestesi inhalasi memerlukan perangkat yang rumit, mahal, dan mempunyai waktu induksi (onset) relatif lambat, serta tidak praktis dalam menangani kasus pembedahan di lapangan. Anestesi inhalasi seperti halotan mengakibatkan keracunan organ dan menyebabkan polusi terhadap individu yang berada di ruangan operasi. Individu yang terpapar halotan subklinis mengakibatkan gangguan hati (Ernawati, 2006). Anestesi inhalasi, seperti gas nitrogen oksida dan anestesi yang diuapkan dengan halogen mengakibatkan pencemaran lingkungan dan penipisan lapisan ozon (Amadasun dan Edomwonyi, 2005).

Anestesi umum injeksi maupun inhalasi pada babi memiliki beberapa kelemahan seperti hipersalivasi, terbatasnya pembuluh darah perifer, bentuk anatomi laring yang menjadi penyulit dalam intubasi trakhea, serta cenderung terjadinya laringospasmus (Geovanini et al., 2008). Babi juga sulit untuk dikekang sehingga penyuntikan intramuskuler atau intravena sulit untuk dilakukan. Dengan kesulitan-kesulitan tersebut, metode pembiusan kombinasi intramuskuler dan intravena yang cepat dan tepat merupakan salah satu solusi pembiusan (Gunanti et al., 2011). Senyawa anestesi intramuskuler yang digunakan harus memiliki onset cepat dan volume pemberian yang sedikit agar pemberian obat bius dapat dengan cepat dilakukan. Karakter mulai kerja obat (onset) yang cepat juga harus memiliki batas keamanan yang luas, langsung memberikan efek hipnosis, serta analgesia (Geovanini et al., 2008).

Metode anestesi alternatif diperlukan untuk mengatasi afek samping penggunaan anestesi umum inhalasi. Anestesi umum dengan metode anestesia injeksi intravena total (TIVA, total intraveous anesthesia) mirip dengan metode anestesi inhalasi, tetapi pompa infus yang digunakan pada metode TIVA harganya mahal (Amadasun dan Edomwonyi, 2005). Metode yang lebih murah, praktis dan paling mungkin untuk mencapai durasi dan pemeliharaan status teranestesi yang lama seperti pada anestesi inhalasi adalah metode injeksi tetes infus intravena yang diberikan secara berulang (metode gravimetrik). Injeksi secara infus intravena memungkinkan distribusi obat lebih lama sehingga dapat memelihara status 
teranestesi lebih lama. Metode infus gravimetrik menggunakan anestetik parenteral melalui tetes infus intravena secara terus menerus. Anestetik dicampur dalam kantong cairan infus dan cairan anestetik dialirkan melalui tetes infus intravena berdasarkan gaya gravitasi dengan dosis dan kecepatan tetes tertentu (Amadasun dan Edomwonyi, 2005).

Anestetik parenteral yang dapat diberikan melalui tetes infus intravena adalah propofol (Bbraun, 2009). Propofol adalah substansi parenteral sebagai agen induksi pada anestesi umum (Wanna et al., 2004) khususnya anestesi inhalasi (Dzikiti et al., 2007). Propofol mempunyai waktu pemulihan yang singkat, tetapi mengakibatkan bradikardia dan pemberian dosis tinggi mengancam nyawa pasien. Ketamin dapat dikombinasikan dengan propofol untuk menurunkan dosis hipnotik propofol dan mengurangi pengaruh depresi kardiovaskuler akibat propofol (Badrinath et al., 2000).

Ketamin hidroklorida adalah anestetik disosiatif dari golongan nonbarbiturat dengan sifat menghilangkan rasa nyeri kuat serta reaksi anestesi tidak menyebabkan ngantuk (Kul et al., 2001). Penghambatan reseptor $N$-methylD-aspartate (NMDA) dengan dosis ketamin rendah menghasilkan analgesik yang baik (Intelisano et al., 2008), tetapi ketamin menyebabkan kekejangan otot dan peningkatan degup jantung (Pathak et al.,1982; Kul et al., 2001).

Mengatasi efek samping ketamin, senyawa tersebut sering dikombinasikan dengan premedikasi sedatif hipnotik golongan á2-adrenoceptor (xilazin) atau golongan benzodiazepin (diazepam, midazolam). Midazolam lebih potensial dibandingkan diazepam. Midazolam dapat mencegah hipertonus otot, meningkatkan efek sedasi dan berefek hipnotik. Penggunaan premedikasi xilazin pada babi menyebabkan muntah, hipersalivasi, dan bradikardia. Pemberian atropin secara bersamaan sebagai premedikasi, dapat menurunkan pengaruh hipersalivasi dan bradikardia dari xilazin.

Dengan demikian, kombinasi atropinxilazin dengan ketamin dan propofol secara gravimetrik melalui tetes infus intravena berpotensi sebagai alternatif anestesi umum inhalasi. Untuk itu, data kualitas anestesi diperlukan apabila digunakan kombinasi tersebut sebagai anestesi untuk durasi anestesi yang panjang pada babi. Tujuan penelitian ini adalah untuk mempelajari pengaruh, dan respons fisiologis penggunaan kombinasi ketaminpropofol (ketapol) yang diberikan secara berulang melalui tetes infus intravena (metode gravimetrik), di samping itu untuk mendapatkan waktu induksi dan durasi pemeliharaan anestesi ketamin-propofol pada babi. Adapun manfaat penelitian adalah untuk memperoleh metode anestesi (tetes gravimetrik) dan dosis kombinasi ketamin-propofol yang aman pada babi sebagai metode anestesi umum yang murah dan praktis terutama digunakan di lapangan sebagai alternatif anestesi umum inhalasi yang rumit dan mahal.

\section{METODE PENELITIAN}

Pada penelitian ini digunakan 12 ekor babi, berbobot $35 \pm 5 \mathrm{~kg}$, umur sekitar tiga bulan, dan jenis kelamin jantan. Babi diadaptasikan dengan suasana kandang selama 21 hari. Dipilih hewan percobaan/pasien dengan klasifikasi status klas I sesuai dengan yang telah ditetapkan oleh American Society of Anesthesiologist. Selama proses adaptasi, semua hewan divaksinasi dengan vaksin septikemia epizootika (SE) dan dibebaskan dari parasit saluran cerna dengan memberikan obat cacing pirantel pamoat.

Sebelum perlakuan (menit ke-0) dilakukan pengukuran terhadap seluruh parameter, dilakukan pengukuran parameter setiap 10 menit (dihitung dari penyuntikan pertama) selama 120 menit. Sebelum perlakuan, hewan dipuasakan makan selama 12 jam dan tidak diberikan air minum tiga jam menjelang perlakuan (Intelisano et al., 2008). Penelitian dilakukan dua tahap yaitu:

Penelitian tahap pertama, menggunakan enam perlakuan dan masing-masing perlakuan terdiri dari dua ekor babi sebagai ulangan. Adapun perlakuannya adalah: 1) AXP: Atropin-xilazin (0,03 dan $2 \mathrm{mg} / \mathrm{kgBB})$ diberikan secara intramuskuler dan 15 menit kemudian diinduksi secara intravena dengan propofol (2 mg/kg BB); 2) AX-K: Atropin-xilazin (0,03 dan $2 \mathrm{mg} / \mathrm{kgBB})$ diberikan secara intramuskuler dan 15 menit kemudian diinduksi secara intravena dengan ketamin (6 mg/kg BB); 3) AX-KP: Atropin-xilazin (0,03 dan $2 \mathrm{mg} / \mathrm{kgBB})$ diberikan secara intramuskuler dan 15 menit kemudian diinduksi secara intravena dengan propofol - ketamin (2 dan 6 mg/kg BB); 4) AM-P: Atropin -midazolam (0,03 dan $0,2 \mathrm{mg} / \mathrm{kgBB}$ ) diberikan secara intramuskuler dan 15 menit kemudian diinduksi secara intravena dengan propofol ( $2 \mathrm{mg} / \mathrm{kg} \mathrm{BB})$; 
5) AM-K: Atropin -midazolam (0,03 dan 0,2 mg/ $\mathrm{kgBB}$ ) diberikan secara intramuskuler dan 15 menit kemudian diinduksi secara intravena dengan ketamin (6 mg/kg BB); 6) AM-KP: Atropin -midazolam (0,03 dan $0,2 \mathrm{mg} / \mathrm{kgBB})$ diberikan secara intramuskuler dan 15 menit kemudian diinduksi secara intravena dengan propofol - ketamin (2 dan $6 \mathrm{mg} / \mathrm{kg} \mathrm{BB}$ ).

Penelitian tahap kedua, babi dipremedikasi dan diinduksi dengan kombinasi terbaik pada penelitian tahap pertama selanjutnya dilakukan empat perlakuan dan masing-masing perlakuan terdiri dari tiga ekor babi sebagai ulangan. Premedikasi dan induksi yang digunakan pada penelitian tahap kedua adalah premedikasi atropin dosis $0,03 \mathrm{mg} / \mathrm{kg}$ dicampur dengan xilazin dosis $2 \mathrm{mg} / \mathrm{kg}$ dalam satu spuit disuntikan secara intramuskuler, 15 menit kemudian diinduksi dengan kombinasi ketamin $6 \mathrm{mg} /$ $\mathrm{kg}$ dan propofol $2 \mathrm{mg} / \mathrm{kg}$ secara intravena. Selanjutnya dilakukan pemeliharaan anestesi secara gravimetrik masing-masing dengan: 1)PI-P, tetes infus intravena dengan propofol $(0,1 \mathrm{mg} / \mathrm{kg} \mathrm{BB} /$ menit$) ;$ 2)PI-K, tetes infus intravena dengan ketamin $(0,3 \mathrm{mg} / \mathrm{kg} \mathrm{BB} /$ menit); 3)PI-PK, tetes infus intravena dengan kombinasi propofol-ketamin $(0,1$ dan $0,3 \mathrm{mg} / \mathrm{kg}$ $\mathrm{BB} /$ menit); dan 4)PI-I, inhalasi dengan isofluran.

\section{Parameter}

Parameter yang diamati dalam penelitian ini adalah: 1) Parameter waktu anestesi meliputi waktu induksi (induction time); waktu anestesi (duration of actions); dan waktu pemulihan (recovery); 2) Parameter respirasi meliputi frekuensi respirasi (respiratory rate); dan nilai saturasi oksigen (SpO2); 3) Parameter kardiovaskuler meliputi frekuensi degup jantung (heart rate); dan nilai capillary refilling time (CRT); dan 4) Parameter suhu rektal (rectal temperature).

\section{Pengukuran Waktu Anestesi}

Waktu induksi (induction time) adalah waktu yang diukur dari awal penyuntikan sampai awal terjadinya anestesia ditandai dengan hilangnya rasa nyeri (manakala babi dijepit pada telinga, ekor, dan interdigitti), hilangnya refleks (palpebral, pupil, dan pedal), dan bola mata menuju ventrocantus. Lama anestesi (duration of actions) adalah waktu yang diukur dari mulai kejadian anestesia sampai hewan mulai sadar (ada gerakan ekor, kaki, telinga, atau kepala), ada respons rasa nyeri (manakala dijepit dengan pinset pada telinga, ekor, dan interdigitti), ada suara dari hewan, ada refleks (palpebral, pupil, dan pedal).

Waktu pemulihan (recovery) adalah waktu yang diukur dari hewan mulai sadar sampai hewan mampu berdiri.

\section{Rancangan Penelitian dan Analisis Statistika}

Rancangan penelitian yang digunakan adalah Rancangan Acak Lengkap (RAL) dan data hasil penelitian dianalisis berdasarkan sidik ragam. Data yang menunjukkan suatu perbedaan yang nyata, dan untuk mengetahui perbedaan antar perlakuan, dilanjutkan dengan Uji Wilayah Berganda Duncan dengan selang kepercayaan 95\% dan 99\% (Rossi dan Junqueira, 2003).

\section{HASIL DAN PEMBAHASAN}

\section{Hasil Penelitian Tahap Pertama}

Nilai rataan waktu induksi, waktu anestesi, dan waktu pemulihan kombinasi ketamin dan propofol yang diberikan premedikasi anestesi dengan atropin sulfat, xilazin dan midazolam pada babi, disajikan pada Tabel 1.

Semua perlakuan kombinasi anestesi yang dilakukan tidak menunjukkan perbedaan yang nyata terhadap waktu induksi. Waktu pemulihan pada perlakuan P2 dan P5 menghasilkan waktu pemulihan yang paling cepat dan berbeda nyata dengan perlakuan lainnya, sedangkan waktu pemulihan perlakuan $\mathrm{P} 1, \mathrm{P} 3, \mathrm{P} 4$, dan P6 tidak menunjukkan perbedaan yang nyata. Waktu anestesi atau durasi anestesi menunjukkan perbedaan yang nyata antar dosis pemberian yang berbeda. Induksi anestesi dengan kombinasi ketamin dan propofol menghasilkan durasi yang nyata lebih lama (P3: $32,33 \pm 3,39$ dan $\mathrm{P} 6: 31,83 \pm 2,23$ menit) dibandingkan dengan perlakuan lainnya $(\mathrm{P} 1, \mathrm{P} 2, \mathrm{P} 4$, dan P5), seperti disajikan pada Gambar 1.

Dari hasil penelitian tahap I diperoleh bahwa perlakuan P3 yaitu perlakuan dengan premedikasi atropin dosis $0,03 \mathrm{mg} / \mathrm{kg}$ dicampur dengan xilazin dosis $2 \mathrm{mg} / \mathrm{kg}$ dalam satu spuit diinjeksi secara intramuskuler, dan 15 menit kemudian diinduksi dengan kombinasi ketamin $6 \mathrm{mg} / \mathrm{kg}$ dan propofol $2 \mathrm{mg} / \mathrm{kg}$ secara intravena menghasilkan rataan lama kerja anestesi selama 32,33 menit lebih lama dibandingkan dengan lima perlakuan lainnya, dengan rataan waktu induksi tiga menit dan rataan waktu 
Tabel 1. Nilai rataan (menit) waktu induksi, waktu anestesi, dan waktu pemulihan kombinasi ketamin dan propofol pada babi.

\begin{tabular}{lccc}
\hline Perlakuan & Waktu Induksi & Waktu Anestesi & Waktu Pemulihan \\
\hline P1 (AX-K) & $2,50 \pm 0,55 \mathrm{a}$ & $9,67 \pm 2,94^{\mathrm{a}}$ & $23,83 \pm 6,31^{\mathrm{a}}$ \\
P2 (AX-P) & $3,17 \pm 0,75 \mathrm{a}$ & $25,17 \pm 2,99^{\mathrm{b}}$ & $5,50 \pm 9,12^{\mathrm{b}}$ \\
P3 (AX-KP) & $2,83 \pm 0,41 \mathrm{a}$ & $32,33 \pm 3,39^{\mathrm{c}}$ & $20,33 \pm 8,62^{\mathrm{a}}$ \\
P4 (AM-K) & $2,67 \pm 0,52 \mathrm{a}$ & $10,83 \pm 2,71^{\mathrm{a}}$ & $28,83 \pm 3,76^{\mathrm{a}}$ \\
P5 (AM-P) & $3,17 \pm 0,75 \mathrm{a}$ & $23,67 \pm 4,27^{\mathrm{b}}$ & $7,33 \pm 2,07^{\mathrm{b}}$ \\
P6 (AM-KP) & $3,00 \pm 0,89 \mathrm{a}$ & $31,83 \pm 2,23^{\mathrm{c}}$ & $29,50 \pm 5,05^{\mathrm{a}}$ \\
\hline
\end{tabular}

Keterangan: P1 (AX-K): Atropin 0,03 mg/kg bb dicampur dalam satu spuit dengan xilazin $2 \mathrm{mg} / \mathrm{kg} \mathrm{bb}$ sebagai premedikasi dan 15 menit kemudian diinduksi dengan ketamin dosis $6 \mathrm{mg} / \mathrm{kg}$ bb secara intra vena; P2 (AX-P): Atropin 0,03 $\mathrm{mg} / \mathrm{kg}$ bb dicampur dalam satu spuit dengan xilazin $2 \mathrm{mg} / \mathrm{kg}$ bb sebagai premedikasi dan 15 menit kemudian diinduksi dengan propofol dosis $2 \mathrm{mg} / \mathrm{kg}$ bb secara intra vena; P3 (AX-KP): Atropin 0,03 mg/kg bb dicampur dalam satu spuit dengan xilazin $2 \mathrm{mg} / \mathrm{kg}$ bb sebagai premedikasi dan 15 menit kemudian diinduksi dengan kombinasi ketamin dosis $6 \mathrm{mg} / \mathrm{kg}$ bb dan propofol dosis $2 \mathrm{mg} / \mathrm{kg}$ bb secara intra vena; $\mathrm{P} 4$ (AM-K): Atropin 0,03 $\mathrm{mg} / \mathrm{kg}$ bb dicampur dalam satu spuit dengan midazolam $0,2 \mathrm{mg} / \mathrm{kg}$ bb sebagai premedikasi dan 15 menit kemudian diinduksi dengan ketamin dosis $6 \mathrm{mg} / \mathrm{kg}$ bb secara intra vena; P5 (AM-P): Atropin $0,03 \mathrm{mg} / \mathrm{kg}$ bb dicampur dalam satu spuit dengan midazolam $0,2 \mathrm{mg} / \mathrm{kg}$ bb sebagai premedikasi dan 15 menit kemudian diinduksi dengan propofol dosis $2 \mathrm{mg} / \mathrm{kg}$ bb secara intra vena; P6 (AM-KP): Atropin 0,03 mg/kg bb dicampur dalam satu spuit dengan midazolam $0,2 \mathrm{mg} / \mathrm{kg}$ bb sebagai premedikasi dan 15 menit kemudian diinduksi dengan kombinasi ketamin dosis $6 \mathrm{mg} / \mathrm{kg}$ bb dan propofol dosis $2 \mathrm{mg} / \mathrm{kg}$ bb secara intra vena.; Pada baris (waktu anestesi) yang sama, huruf (a,b,c,) yang berlainan menunjukkan berbeda nyata $(\mathrm{P}<0,05)$, huruf $(a, \hat{a}, d, a ̃)$ yang berlainan menunjukkan berbeda sangat nyata $(\mathrm{P}<0,01)$.

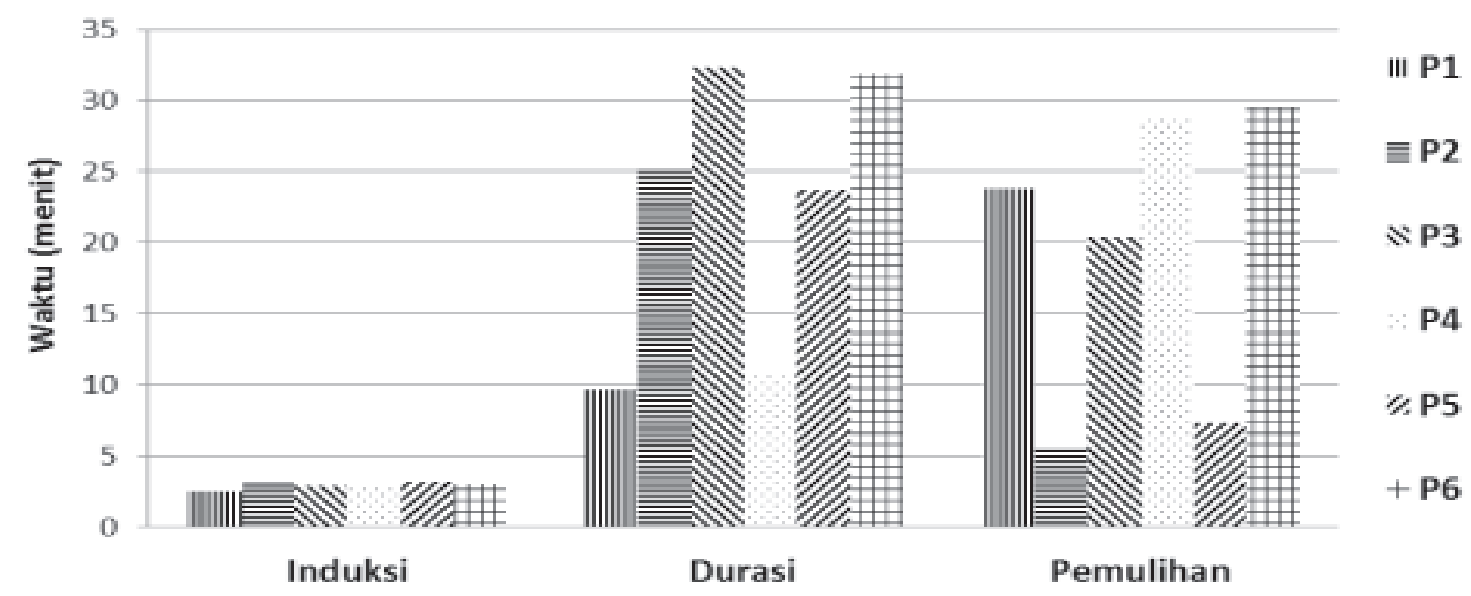

Gambar 1. Nilai rataan (menit) waktu induksi, waktu anestesi, dan waktu pemulihan pemberian ketamin dan propofol pada babi

Keterangan : P1 (AX-K): Atropin 0,03 mg/kg bb dicampur dalam satu spuit dengan xilazin $2 \mathrm{mg} / \mathrm{kg} \mathrm{bb}$ sebagai premedikasi dan 15 menit kemudian diinduksi dengan ketamin dosis $6 \mathrm{mg} / \mathrm{kg} \mathrm{bb}$ secara intra vena; P2 (AX-P): Atropin $0,03 \mathrm{mg} / \mathrm{kg}$ bb dicampur dalam satu spuit dengan xilazin $2 \mathrm{mg} / \mathrm{kg}$ bb sebagai premedikasi dan 15 menit kemudian diinduksi dengan propofol dosis $2 \mathrm{mg} / \mathrm{kg}$ bb secara intra vena; P3 (AX-KP): Atropin $0,03 \mathrm{mg} / \mathrm{kg}$ bb dicampur dalam satu spuit dengan xilazin $2 \mathrm{mg} / \mathrm{kg}$ bb sebagai premedikasi dan 15 menit kemudian diinduksi dengan kombinasi ketamin dosis $6 \mathrm{mg} / \mathrm{kg}$ bb dan propofol dosis $2 \mathrm{mg} / \mathrm{kg}$ bb secara intra vena; P4 (AM-K): Atropin 0,03 mg/kg bb dicampur dalam satu spuit dengan midazolam $0,2 \mathrm{mg} / \mathrm{kg}$ bb sebagai premedikasi dan 15 menit kemudian diinduksi dengan ketamin dosis $6 \mathrm{mg} / \mathrm{kg} \mathrm{bb}$ secara intra vena; P5 (AM-P): Atropin $0,03 \mathrm{mg} / \mathrm{kg}$ bb dicampur dalam satu spuit dengan midazolam $0,2 \mathrm{mg} / \mathrm{kg}$ bb sebagai premedikasi dan 15 menit kemudian diinduksi dengan propofol dosis $2 \mathrm{mg} / \mathrm{kg}$ bb secara intra vena; P6 (AM-KP): Atropin 0,03 mg/kg bb dicampur dalam satu spuit dengan midazolam $0,2 \mathrm{mg} / \mathrm{kg}$ bb sebagai premedikasi dan 15 menit kemudian diinduksi dengan kombinasi ketamin dosis $6 \mathrm{mg} / \mathrm{kg}$ bb dan propofol dosis $2 \mathrm{mg} / \mathrm{kg}$ bb secara intra vena. 
pemulihan 20,33 menit. Perlakuan P3 digunakan untuk penelitian tahap kedua untuk pembuktian respons fisiologis kombinasi anestesi ketamin-propofol yang diinjeksikan melalui tetes infus intravena (gravimetrik) untuk memelihara durasi anestesi yang panjang sebagai alternatif anestesi umum inhalasi pada babi.

\section{Hasil Penelitian Tahap Kedua}

Degup Jantung. Nilai rataan frekuensi degup jantung babi sebelum perlakuan anestesi (menit ke-0) dan selama teranestesi dengan masing-masing kombinasi anestesi ketamin dan propofol serta pengulangannya, disajikan pada Gambar 2.

Perlakuan pemeliharaan anestesi dengan propofol, kombinasi ketamin-propofol dan isofluran (PI-P, PI-PK, dan PI-Iso) menunjukkan pola perubahan degup jantung yang sama. Selama teranestesi, terjadi penurunan nilai rataan degup jantung dengan sebelum dilakukan anestesi (menit ke-0). Penurunan degup

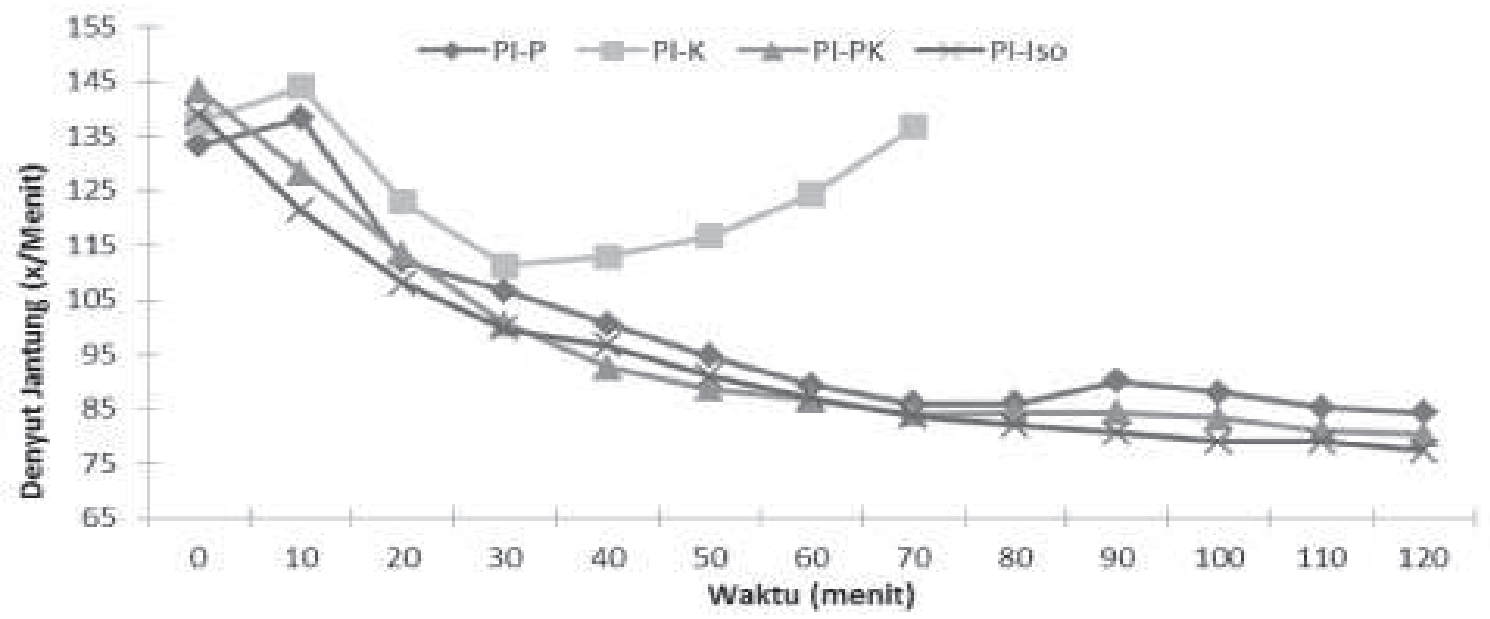

Gambar 2. Perubahan nilai rataan degup jantung sebelum teranestesi (menit ke-0) dan selama teranestesi dengan kombinasi ketamin dan propofol secara gravimetrik pada babi.

Keterangan: $\mathrm{PI}=$ premedikasi atropin $0,03 \mathrm{mg} / \mathrm{kg}+$ xilazin dosis $2 \mathrm{mg} / \mathrm{kg}$ dalam satu spuit, 15 menit diinduksi ketamin $6 \mathrm{mg} / \mathrm{kg}$ dan propofol $2 \mathrm{mg} / \mathrm{kg}$ secara intravena. $-\mathbf{P}=$ tetes infus intravena dengan Propofol (0,1 mg/kg BB/menit); -K= tetes infus intravena dengan Ketamin (0,3 mg/kg $\mathrm{BB} /$ menit); $\mathbf{- P K}=$ tetes infus intravena dengan kombinasi Propofol-Ketamin (0,1 dan 0,3 mg/ $\mathrm{kg} \mathrm{BB/menit);} \mathrm{dan} \mathrm{-Iso=} \mathrm{inhalasi} \mathrm{dengan} \mathrm{isofluran.}$

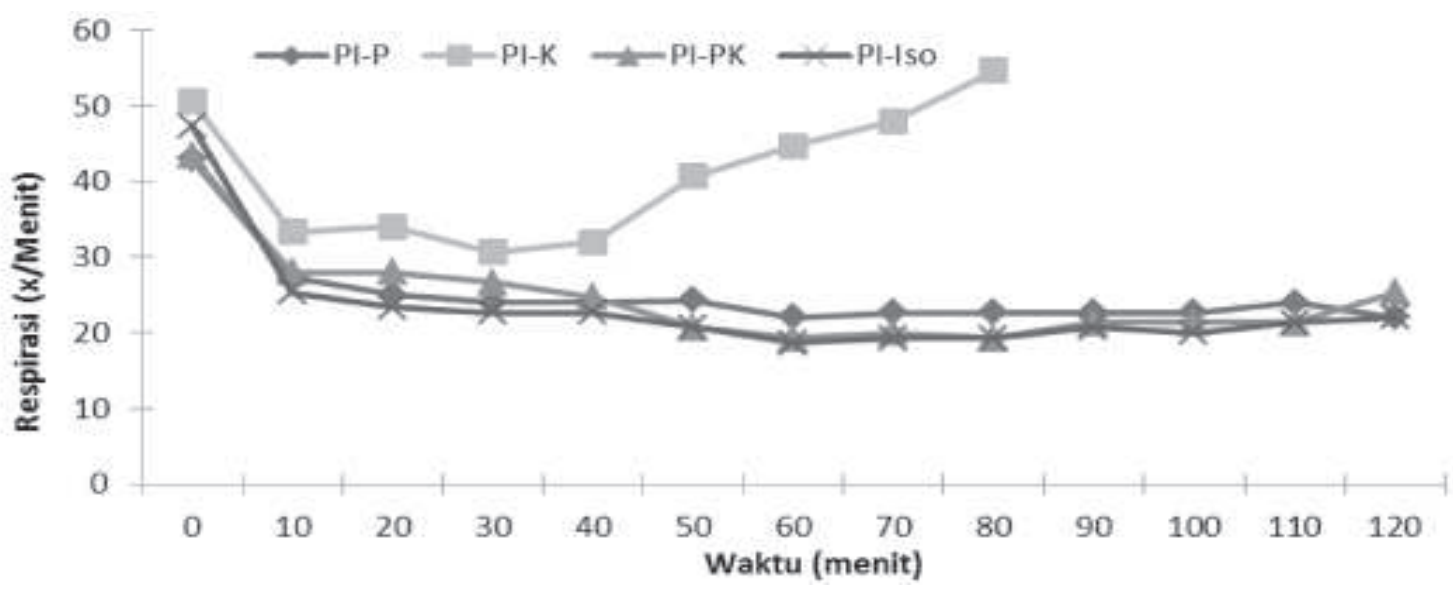

Gambar 3. Perubahan nilai rataan respirasi sebelum teranestesi (menit ke-0) dan selama teranestesi dengan kombinasi ketamin dan propofol secara gravimetrik pada babi.

Keterangan: $\mathrm{PI}=$ premedikasi atropin $0,03 \mathrm{mg} / \mathrm{kg}+$ xilazin dosis $2 \mathrm{mg} / \mathrm{kg}$ dalam satu spuit, 15 menit diinduksi ketamin $6 \mathrm{mg} / \mathrm{kg}$ dan propofol $2 \mathrm{mg} / \mathrm{kg}$ secara intravena. $-\mathbf{P}=$ tetes infus intravena dengan Propofol (0,1 mg/kg BB/menit); -K= tetes infus intravena dengan Ketamin $(0,3 \mathrm{mg} / \mathrm{kg}$ $\mathrm{BB} /$ menit); -PK= tetes infus intravena dengan kombinasi Propofol-Ketamin (0,1 dan 0,3 mg/ $\mathrm{kg} \mathrm{BB} /$ menit); dan $-\mathbf{I s o =}$ inhalasi dengan isofluran. 
jantung yang sangat tajam terjadi sampai menit ke-70, selanjutnya mulai terjadi peningkatan dan stabil sekitar 85 kali per menit sampai akhir perlakuan anestesi. Hal ini disebabkan karena potensi dosis premedikasi xilazin sangat kuat menyebabkan penurunan degup jantung sampai menit ke-70, peranan premedikasi atropin dosis $0,03 \mathrm{mg} / \mathrm{kg}$ BB dan induksi ketamin $6 \mathrm{mg} / \mathrm{kg}$ BB belum cukup untuk meningkatkan degup jantung akibat xilazin $2 \mathrm{mg} / \mathrm{kg}$ BB. Pemeliharaan status teranestesi secara tetes infus intravena dengan propofol $0,1 \mathrm{mg} / \mathrm{kg} \mathrm{BB} /$ menit, tetes infus intravena dengan kombinasi propofolketamin $(0,1$ dan $0,3 \mathrm{mg} / \mathrm{kg} \mathrm{BB} /$ menit$)$, dan dengan isofluran, tidak menyebabkan peningkatan degup jantung yang nyata akibat premedikasi xilazin. Tetapi pemeliharaan status teranestesi melalui tetes infus intravena dengan ketamin $0,3 \mathrm{mg} / \mathrm{kg} \mathrm{BB} /$ menit menyebabkan peningkatan degup jantung menuju normal dan status teranestesi tidak dapat dipertahankan (hewan sadar). Hal ini membuktikan bahwa propofol menimbulkan pengaruh yang tidak nyata terhadap degup jantung (Mohamadnia et al., 2008). Belo et al., (1994), menyatakan bahwa propofol menyebabkan penurunan tekanan darah tetapi tidak menyebabkan perubahan pada degup jantung. Sehingga infus dengan propofol dapat menyebabkan penurunan degup jantung adalah akibat pengaruh preanestesi xilazin $\mathrm{HCl}$ sangat kuat menurunkan degup jantung. Pemeliharaan status teranestesi melalui tetes infus gravimetrik dengan kombinasi ketaminpropofol dosis masing-masing 0,3 dan $0,1 \mathrm{mg} /$ $\mathrm{kg} /$ menit dan pemeliharaan dengan isofluran memberikan pengaruh yang tidak berbeda terhadap degup jantung serta tidak menyebabkan perubahan degup jantung yang ekstrim dan tetap stabil sampai akhir anestesi.

Frekuensi Respirasi. Nilai rataan frekuensi respirasi babi sebelum perlakuan (menit ke-0) dan selama teranestesi dengan kombinasi ketamin dan propofol serta pemeliharaan anestesinya, disajikan pada Gambar 3.

Perlakuan induksi anestesi dengan ketamin-propofol dan pemeliharaan status teranestesi secara tetes infus intravena (gravimetrik) dengan kombinasi ketamin-propofol (PI$\mathrm{PK}$ ), pemeliharan status teranestesi dengan propofol, dan isofluran menunjukkan pola perubahan nilai respirasi yang sama. Selama teranestesi, terjadi penurunan nilai rataan respirasi dengan sebelum dilakukan anestesi (menit ke-0). Penurunan nilai respirasi tidak tajam dan selanjutnya stabil sekitar 25 kali per menit sampai akhir perlakuan anestesi. Hal ini disebabkan karena terjadi relaksasi otot-otot di antara tulang iga dan perut yang dapat mengembang-kempiskan rongga dada sewaktu terjadi respirasi, karena xilazin tergolong muscle relaxant. Xilazin termasuk golongan a2-adrenergik agonis, dikombinasikan dengan ketamin menyebabkan terjadinya sedasi dan tertekannya respirasi (Rossi dan Junqueira, 2003), sedangkan pada perlakuan pemeliharaan status teranestesi secara tetes intravena dengan ketamin $0,3 \mathrm{mg} /$ $\mathrm{kg} \mathrm{BB} /$ menit menyebabkan peningkatan respirasi menuju normal pada menit ke-60 dan status teranestesi tidak dapat dipertahankan (hewan telah sadar).

Suhu Rektal. Nilai rataan suhu rektal babi sebelum perlakuan (menit ke-0) dan selama teranestesi dengan kombinasi ketamin dan propofol dan pemeliharaan anestesi secara gravimetrik pada babi, disajikan pada Gambar 4.

Penurunan suhu rektal sampai akhir anestesi terjadi pada kombinasi anestesi dengan premedikasi atropin-xilazin dan induksi dengan ketamin-propofol serta pemeliharaan status teranestesi dengan propofol, ketamin-propofol, dan isofluran. Pemeliharaan status teranestesi dengan ketamin saja terjadi penurunan suhu rektal sampai menit ke-40, selanjutnya suhu rektal meningkat menuju normal dan status teranestesi tidak dapat dipertahankan dengan pemberian ketamin (hewan telah sadar). Hal ini disebabkan karena pada keadaan teranestesi laju metabolisme tubuh menurun sehingga proses pembentukan energi tubuh yang menghasilkan panas juga menurun. Penggunaan xilazin menyebabkan penurunan suhu rektal yang sangat nyata, karena xilazin menyebabkan sedasi, penurunan metabolisme, relaksasi otot dan tertekannya susunan saraf pusat serta menyebabkan penekanan termoregulasi yang lebih lama (Rossi dan Junqueira, 2003).

Saturasi Oksigen. Nilai rataan saturasi oksigen babi sebelum perlakuan (menit ke-0) dan selama teranestesi dengan kombinasi ketamin dan propofol dan pemeliharaan anestesi secara gravimetrik pada babi, disajikan pada Gambar 5.

Pola perubahan nilai saturasi oksigen respirasi selama babi dalam keadaan teranestesi tidak menunjukkan perubahan yang berbeda nyata, begitu pula antar perlakuan tidak menunjukkan perbedaan yang nyata. Hal ini disebabkan karena perlakuan anestesi tidak mengakibatkan perubahan terhadap volume tidal dan nilai $\mathrm{O}_{2}$ respirasi. Greene dan Thurmon 


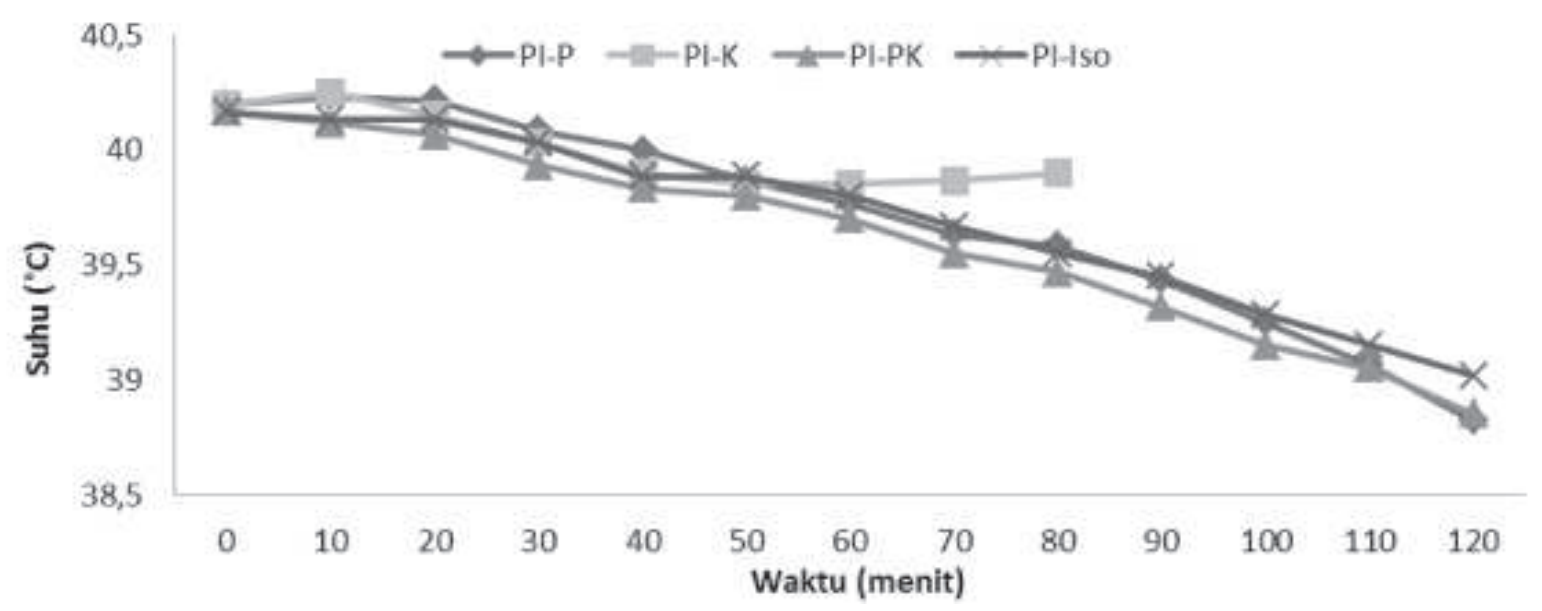

Gambar 4. Perubahan nilai rataan suhu rektal sebelum teranestesi (menit ke-0) dan selama teranestesi dengan kombinasi ketamin dan propofol secara gravimetrik pada babi.

Keterangan: $\mathrm{PI}=$ premedikasi atropin $0,03 \mathrm{mg} / \mathrm{kg}+$ xilazin dosis $2 \mathrm{mg} / \mathrm{kg}$ dalam satu spuit, 15 menit diinduksi ketamin $6 \mathrm{mg} / \mathrm{kg}$ dan propofol $2 \mathrm{mg} / \mathrm{kg}$ secara intravena. $-\mathbf{P}=$ tetes infus intravena dengan Propofol (0,1 mg/kg BB/menit); -K= tetes infus intravena dengan Ketamin (0,3 mg/kg BB/menit); -PK= tetes infus intravena dengan kombinasi Propofol-Ketamin (0,1 dan 0,3 mg/ $\mathrm{kg} \mathrm{BB/menit);} \mathrm{dan} \mathrm{-Iso=} \mathrm{inhalasi} \mathrm{dengan} \mathrm{Isofluran.}$

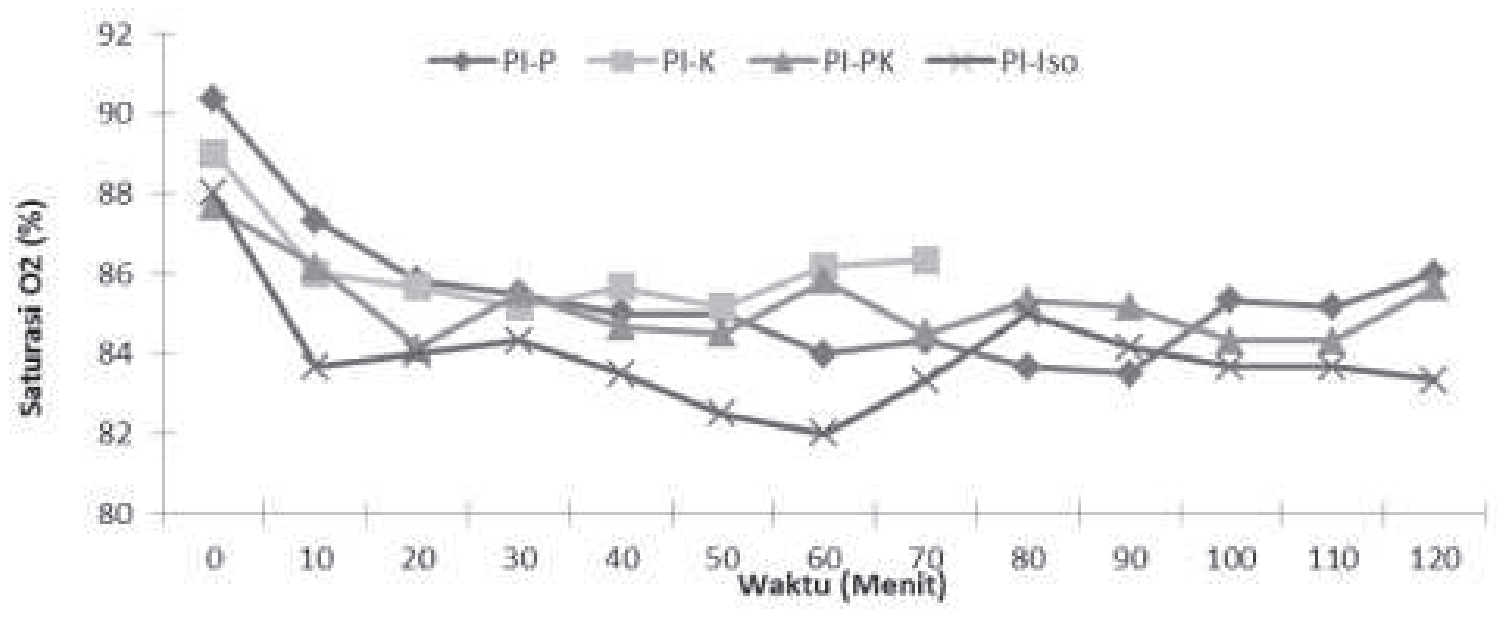

Gambar 5 Perubahan nilai rataan saturasi oksigen sebelum teranestesi (menit ke-0) dan selama teranestesi dengan kombinasi ketamin dan propofol secara gravimetrik pada babi.

Keterangan: $\mathrm{PI}=$ premedikasi atropin $0,03 \mathrm{mg} / \mathrm{kg}+$ xilazin dosis $2 \mathrm{mg} / \mathrm{kg}$ dalam satu spuit, 15 menit diinduksi ketamin $6 \mathrm{mg} / \mathrm{kg}$ dan propofol $2 \mathrm{mg} / \mathrm{kg}$ secara intravena. $-\mathbf{P}=$ tetes infus intravena dengan Propofol (0,1 mg/kg BB/menit); -K= tetes infus intravena dengan Ketamin (0,3 mg/kg $\mathrm{BB} /$ menit); -PK= tetes infus intravena dengan kombinasi Propofol-Ketamin ( 0,1 dan 0,3 mg/ $\mathrm{kg} \mathrm{BB} /$ menit); dan -Iso= inhalasi dengan Isofluran.

(1988) menyatakan bahwa tidak ditemukan perubahan tekanan $\mathrm{O}_{2}$ dan $\mathrm{CO}_{2}$ setelah penyuntikan xilazin maupun induksi dengan ketamin dan propofol pada anjing.

Pulsus. Nilai rataan pulsus babi sebelum perlakuan anestesi (menit ke-0) dan selama teranestesi dengan kombinasi ketamin dan propofol dan pemeliharaan anestesi secara gravimetrik pada babi, disajikan pada Gambar
6.

Pola perubahan pulsus babi selama teranestesi dengan kombinasi ketamin dan propofol secara gravimetrik menunjukkan nilai yang sama. Selama teranestesi, terjadi penurunan nilai rataan pulsus dengan sebelum dilakukan anestesi (menit ke-0). Penurunan pulsus yang tajam sejalan dengan degup jantung terjadi sampai menit ke-70, selanjutnya stabil 
sekitar 88 kali per menit sampai akhir perlakuan anestesi. Hal ini disebabkan karena potensi xilazin yang menyebabkan menurunnya transmisi simpatik dari susunan saraf pusat, tertekannya pacemaker, dan meningkatnya tonus vagal (Rossi dan Junqueira, 2003). Xilazin menyebabkan aktivitas simpatik menurun dan aktivitas vagal meningkat (Kul, 2001). Xilazin lebih kuat menutupi pengaruh peningkatan aktivitas simpatik dan penurunan tonus vagal oleh ketamin (Haskin et al., 1985; Wixson et al., 1987). Penggunaan dosis propofol belum memberikan pengaruh yang nyata terhadap perubahan pulsus babi selama teranestesi. Peru-

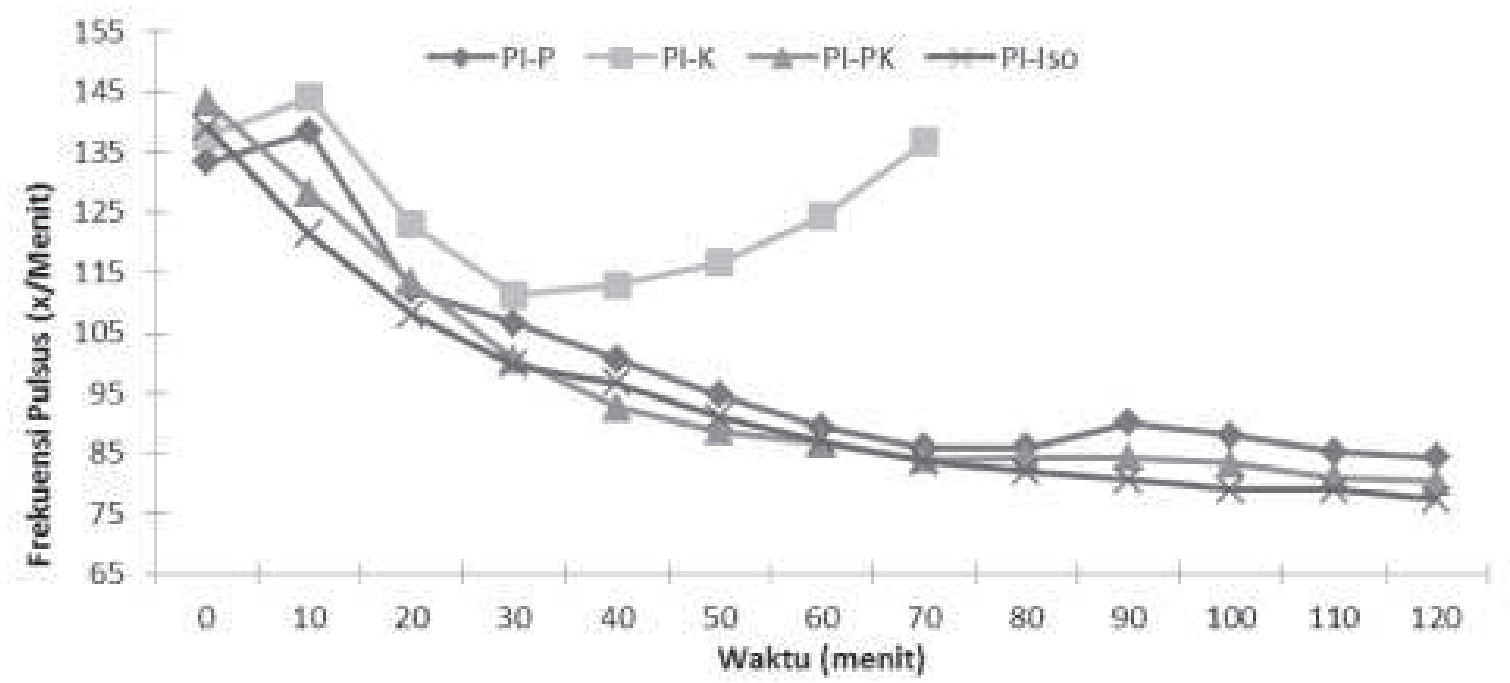

Gambar 6. Perubahan nilai rataan pulsus sebelum teranestesi (menit ke-0) dan selama teranestesi dengan kombinasi ketamin dan propofol secara gravimetrik pada babi.

Keterangan: PI= premedikasi atropin $0,03 \mathrm{mg} / \mathrm{kg}+$ xilazin dosis $2 \mathrm{mg} / \mathrm{kg}$ dalam satu spuit, 15 menit diinduksi ketamin $6 \mathrm{mg} / \mathrm{kg}$ dan propofol $2 \mathrm{mg} / \mathrm{kg}$ secara intravena. $-\mathbf{P}=$ tetes infus intravena dengan Propofol (0,1 mg/kg BB/menit); $\mathbf{K}=$ tetes infus intravena dengan Ketamin (0,3 mg/ $\mathrm{kg} \mathrm{BB/menit);-PK=} \mathrm{tetes} \mathrm{infus} \mathrm{intravena} \mathrm{dengan} \mathrm{kombinasi} \mathrm{Propofol-Ketamin} \mathrm{(0,1} \mathrm{dan} \mathrm{0,3}$ $\mathrm{mg} / \mathrm{kg} \mathrm{BB} / \mathrm{menit})$; dan -Iso= inhalasi dengan Isofluran.

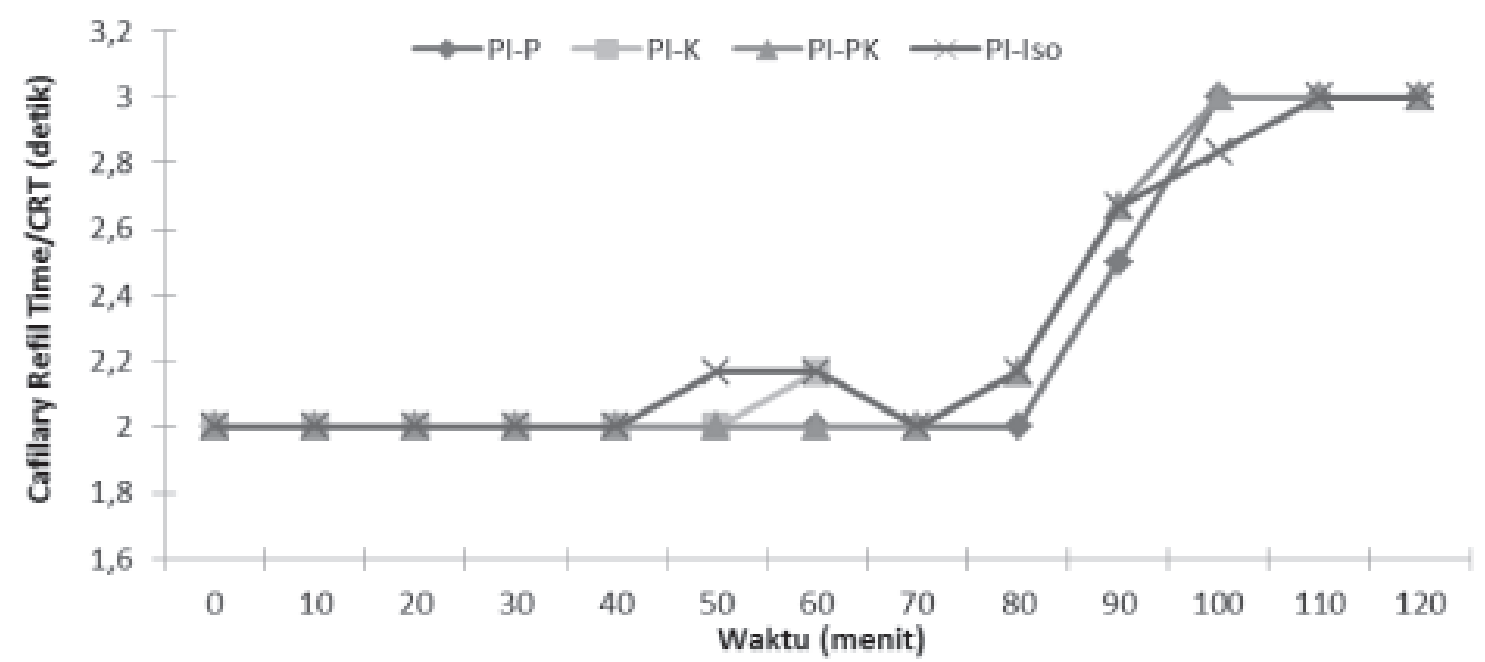

Gambar 7. Perubahan rataan nilai pulsus sebelum teranestesi (menit ke-0) dan selama teranestesi dengan kombinasi ketamin dan propofol secara gravimetrik pada babi.

Keterangan: $\mathrm{PI}=$ premedikasi atropin $0,03 \mathrm{mg} / \mathrm{kg}+$ xilazin dosis $2 \mathrm{mg} / \mathrm{kg}$ dalam satu spuit, $15 \mathrm{menit}$ diinduksi ketamin $6 \mathrm{mg} / \mathrm{kg}$ dan propofol $2 \mathrm{mg} / \mathrm{kg}$ secara intravena. $-\mathbf{P}=$ tetes infus intravena dengan Propofol (0,1 mg/kg BB/menit); $-\mathbf{K}=$ tetes infus intravena dengan Ketamin (0,3 mg/ kg BB/menit); -PK= tetes infus intravena dengan kombinasi Propofol-Ketamin (0,1 dan 0,3 $\mathrm{mg} / \mathrm{kg} \mathrm{BB} / \mathrm{menit}) ;$ dan $-\mathbf{I s o}=$ inhalasi dengan Isofluran 
bahan pulsus babi selama teranestesi sejalan dengan perubahan degup jantung. Propofol menimbulkan pengaruh yang tidak nyata terhadap degup jantung (Mohamadnia et al., 2008), sehingga perubahan pulsus akibat propofol juga tidak nyata. Belo et al. (1994), menyatakan bahwa propofol menyebabkan penurunan tekanan darah tetapi tidak menyebabkan perubahan pada degup jantung. Sehingga infus dengan propofol menyebabkan penurunan degup jantung dan penurunan pulsus adalah akibat pengaruh premedikasi xilazin.

Capillary Refilling Time (CRT). Capillary refilling time menandakan adanya aliran darah pada jaringan. Nilai CRT menandakan pengisian kapiler atau aliran darah pada jaringan perifir. Nilai CRT meningkat menandakan pengisian jaringan oleh darah tidak optimal atau aliran darah ke jaringan menurun, yaitu lebih dari dua detik. Perubahan yang nyata terjadi setelah menit ke-70, perubahan nilai CRT setelah menit ke-70 menunjukkan lebih lama dari pada nilai awalnya, disajikan pada Gambar 7 .

Nilai CRT mengalami pola peningkatan pada menit ke-80 sampai menit ke-90 pada perlakuan pemeliharaan status anestesi dengan propofol, kombinasi propofol-ketamin dan isofluran. Hal ini disebabkan karena pengaruh xilazin sebagai premedikasi yang mempunyai pengaruh sangat kuat menurunkan degup jantung sehingga aliran darah juga menurun. Penurunan curah jantung dan dilatasi pembuluh darah perifer dapat menyebabkan meningkatnya nilai CRT (Rossi dan Junqueira, 2003; Kul, 2001).

Pemeliharaan status teranestesi melalui infus gravimetrik dengan kombinasi ketaminpropofol menyebabkan nilai CRT lebih lama. Hal ini disebabkan karena propofol mempunyai potensi mendepresi respirasi dan menyebabkan penurunan metabolik (Seymour dan Novakovski, 2007). Efek samping penggunaaan propofol adalah hipotensi, apnea, dan rasa nyeri pada tempat penyuntikan (Stawicki, 2007). Propofol menyebabkan turunnya tekanan darah karena secara langsung menyebabkan vasodilatasi pada vena dan arteri dan menyebabkan relaksasi pembuluh darah (Karsli et al., 1999), sehingga nilai CRT untuk mengisi pembuluh darah perifer menjadi lebih lama. Pada pemeliharaan status anestesi dengan hanya menggunakan ketamin, terjadi penurunan CRT mulai menit ke-60 seiring dengan mulai sadarnya hewan tersebut sehingga aliran darah menuju kejaringan perifer semakin meningkat.

\section{SIMPULAN}

Metode anestesi melalui tetes infus gravimetrik dengan kombinasi ketamin dan propofol (ketafol) dapat digunakan sebagai pilihan pemeliharaan status teranestesi pada babi sebagai alternatif pengganti anestesi umum inhalasi yang mahal dan rumit.

\section{SARAN}

Perlu dilakukan pemeriksaan terhadap parameter toksisitas dan hematologi terutama terhadap fungsi hati dan ginjal setelah pemberian kombinasi ketamin dan propofol secara gravimetrik dalam waktu yang lama lebih dari 120 menit.

\section{UCAPAN TERIMA KASIH}

Terimakasih disampaikan pada Fakultas Kedokteran Hewan, Universitas Udayana melalui alokasi sumber dana Hibah Unggulan Program Studi Tahun 2016 yang telah mendanai penelitian ini.

\section{DAFTAR PUSTAKA}

Amadasun FE, Edomwonyi NP. 2005. Evaluation of the gravimetric method of propofol infusion with intermittent ketamine injections for total intravenous anaesthesia (TIVA). JMBR 4: 65-70.

Bbraun. 2009. Propofol-Lipuro. Basic scientific information. Germany: Bbraun Melsungen.

Belo SE, Kolesar R, Mazer CD. 1994. Intracoronary propofol does not decrease myocardial contractile function in the dogs. Can J Anesth 4: 43-49

Dzikiti TB, Chanaiwa S, Mponda P, Sigauke C, Dzikiti LN. 2007. Comparison of quality of induction of anaesthesia between intramuscullary administered ketamin, intravenously administered ketamine and intravenously administered propofol in xylazine premedicated cats. $J$ South African Vet Assoc 78: 201-204.

Ernawati MDW. 2006. Pengaruh paparan udara 
halotan dengan dosis subanestesi terhadap gangguan hati mencit. Jurnal Sains dan Teknologi Farmasi 11: 71-75.

Franks NP. 2008. General anaesthesia: from molecular targets to neuronal athways of sleep and arousal. Nature Reviews Neuroscience. 9: 370-386. www.nature.com/ reviews/neuro. [24 Juli 2009].

Geovanini GR, Pinna FR, Prado FAP, Tamaki WT, Marques E. 2008. Standardization of anesthesia in swine for experimental cardiovasculer surgeries. Rev Bras Anesthesial 58(4): 363-370.

Greene SA, Thurmon TC. 1988. Xylazine a review of its pharmacology and use in veterinary medicine. Journal of Veterinary Pharmacology and Therapeutics 11: 295313.

Gunanti, Riki S, Soehartono RH, Ulum MF, Sudisma IGN. 2011. Pembiusan babi model laparoskopi untuk manusia dengan zoletyl, ketamin dan xilazin. J Veteriner 12(4): 247 253.

Haskin SC, Farver TB, Patz JD. 1985. Ketamine in dog. Am $J$ Vet 9: $1855-1860$.

Intelisano TR, Kitahara FR, Otsuki DA, Fantoni DT, Auler JOC, Cortopassi SRG. 2008. Total intravenous anaesthesia with propofolracemic ketamine and propofol-S-ketamine: a comparative study and haemodynamic evaluation in dogs undergoing ovariohysterectomy. Pesquisa Veterinaria Brasileira 28: 216-222.

Karsli B, Kaya T, Sarioglu Y. 1999. Effects of ketamine, propofol and midazolam on spontaneus contractions of isolated pregnant rat myometrium. T Klin J Med Res 17: 7076.

Kul M, Koc Y, Alkan F, Ogurtan Z. 2001. The effects of xilasine-ketamine and diazepamketamine on arterial blood pressure and blood gases in dog. OJVR 4: 124-132.
Mashour GA. 2006. Integrating the science of consciousness and anesthesia. Anesth Analg 103: 975-982.

Mohamadnia, AR, Shabazkia, H, Akhlaghi M, Shahrokhi M, Saberin L. 2008. Clinical evaluation of repeated propofol total intravenous anesthesia in dog. Pakistan Journal of Biological Sciences 11: 18201824.

Pathak SC, Migan JM, Peshin PK, Singh AP. 1982. Anesthetic and Hemodynamic Effecs of Ketamine Hydrochloride in Buffalo Calves. Am J Vet 5: 875-877.

Pretto EA. 2002. Pursuing the holy grail of anesthesia. Anesthesiology News 1: 1-9.

Rossi RD, Junqueira AL. 2003. Analgesic and systemic effect of ketamin, xylazine, and lidocaine after subarachnoid administration in goats. Am $J$ Vet Res 64: 51-56.

Stawicki SP . 2007. Common sedative agents. OPUS 12 Sciestist 1: 8-9.

Wanna, Werawatganon T, Piriyakitphaiboom S, Taesiri B. 2004. A comparison of propofol and ketamine as induction agents for cesarean section. J Med Assoc Thai 87: 774-779.

Wixson SK, White WJ, Hughes HC, Lang CM, Marshall WK. 1987. The effects of pentobarbital, fentanyl-droperidol, ketaminxylazine and ketamine-diazepam on arterial blood $\mathrm{pH}$, blood gases, mean arterial blood pressure and heart rate in adult male rats. Laboratory Animal Science 37: 736-742. 